\section{Oxygen Equilibria of Red Cell Hæmolysates of Adult Individuals, Heterozygous for Different Rare Abnormal Hæmoglobins}

IN the past few years, oxygen equilibria of various normal and abnormal adult human hæmoglobin types have been studied. No differences were observed between normal Hb-A $\left(\alpha_{2} \beta_{2}\right)$ and the $\beta$-chain abnormalities Hb-s (ref. 1), $\mathrm{Hb} \cdot \mathrm{C}$ (ref. 2) and Hb-F (ref. 3). Investigations of the isolated Hb- $\mathrm{A}_{2}^{\prime}\left(\alpha_{2} \delta_{2}\right)$ and its abnormal variant $\mathrm{Hb}-\mathrm{A}_{2}$ revealed a considerable increase in oxygen affinity when compared with normal Hb-A (ref. 4). Hb-Lepore, which is composed of normal $\alpha$-chains and ' $\beta$ ' chains being related to the $\beta$-chain of $\mathrm{Hb}$-A as well as to the $\delta$-chain of $\mathrm{Hb}-\mathrm{A}_{2}$ (ref. 5), showed a high affinity for molecular oxygen similar to that of $\mathrm{Hb}-\mathrm{A}_{2}$ (ref. 1). The affinities of the $x$-chain lacking abnormal hæmoglobin types $\mathrm{Hb}-\mathrm{H}\left(\beta_{4}\right)$ and Hb-Bart's $\left(\gamma_{4}\right)$ for molecular oxygen were found to be extremely high, while no Bohr effect or hæm-hæm interactions were detectable $e^{6,7}$.

This investigation was an additional step in our search for possible functional alterations of different abnormal human hæmoglobin types. The experimental situation made it necessary to limit our investigations to the determination of the oxygen affinity of red blood cell hæmolysates obtained from adult individuals, known to be heterozygous for various $\alpha$ - or $\beta$-chain abnormalities. The methods used for the oxygen equilibria determination and for the quantitation of abnormal components either by CM- or DEAE-cellulose chromatography have been described before ${ }^{1,8,9}$. Four $\beta$-chain abnormalities and three $\alpha$-chain abnormalities were investigated. The electrophoretically fast-moving $\beta$-chain abnormalities, $\mathbf{H b}-\mathbf{J}_{\text {Georgia }}$ (ref. 10) and Hb-Jenkins (ref. 11), each found in two Negro families, were present in the blood of hetero\%ygous carriers in quantities exceeding 50 per cent (Table 1). The quantities of Hb.Dpuniab (ref. 12), discovered in several members of two families of Caucasian extraction, and of another Hb-D with unknown structural alteration of the $\beta$-chain, discovered in a Negro family (fam. M), were approximately one-third of the total hæmoglobin (Table 1). The three major $\alpha$-chain abnormal hemoglobins, $\mathrm{Hb}-\mathrm{D} \alpha$, found in two members of a Negro family, the electrophoretically fast-moving $\mathrm{Hb}-\mathrm{I}$ (ref. 13) and Hb-Russ (ref. 14), both discovered in members of families of Caucasian extraction, were present in different quantities; the percentage of $\mathrm{Hb}-\mathrm{D} \alpha$ amounted to approximately one-third, that of $\mathrm{Hb}-\mathrm{I}$ to approximately one-fifth and that of $\mathrm{Hb}$-Russ to approximately one-tenth of the total hæmoglobin present in the red cell hæmolysates of heterozygous carriers (Table 1).

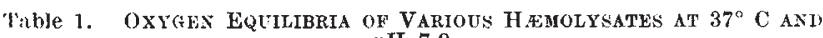

\begin{tabular}{|c|c|c|c|c|c|c|}
\hline \multirow[b]{2}{*}{$\begin{array}{c}\text { Type of } \\
\text { hæmolysates }\end{array}$} & \multicolumn{4}{|c|}{$p \mathrm{H} 7$} & \multirow[b]{2}{*}{$\underset{P_{50}}{4 \log }$} & \multirow[b]{2}{*}{$\mathrm{n}$} \\
\hline & $\begin{array}{c}\text { Ab- } \\
\text { normal } \\
\text { chain }\end{array}$ & Abn. ${ }^{\%} \mathrm{Hb}$. & $\begin{array}{l}\% \\
\mathrm{~A}_{2}\end{array}$ & $\stackrel{\operatorname{Iog}}{\mathbf{P}_{50}{ }^{*}}$ & & \\
\hline $\begin{array}{l}\text { Yormal } \\
\text { Hb-JGeorgia } \\
\text { Hb-Jenkins } \\
\text { Hb-D (Fam. M) }\end{array}$ & $\begin{array}{l}\beta \\
\beta \\
\beta\end{array}$ & $\begin{array}{l}55.5 \\
51.7 \\
37.8\end{array}$ & $\begin{array}{l}2 \cdot 3-2 \cdot 7 \\
2 \cdot 3 \\
2 \cdot 3 \\
2 \cdot 4\end{array}$ & $\begin{array}{l}1.280 \\
1.280 \\
1.275 \\
1.270\end{array}$ & $\begin{array}{c}0 \\
-0.005 \\
-0.010\end{array}$ & $\begin{array}{l}3 \cdot 2 \\
3 \cdot 2 \\
3 \cdot 1: 2 \\
3 \cdot 2\end{array}$ \\
\hline $\begin{array}{l}\text { Hb-DPunjab } \\
\text { Fam.Jon. }\end{array}$ & $\beta$ & 35 & 2. & & & $3 \cdot 2$ \\
\hline $\operatorname{Fam}_{\text {Ifb-D }} \underset{\text { Fram. J) }}{E}$ & $a$ & $\begin{array}{l}34.2 \\
32.9\end{array}$ & $1.4 \dagger$ & $1 \cdot 270$ & $\begin{array}{l}-0.030 \\
-0.010\end{array}$ & $\begin{array}{l}3 \cdot 2 \\
3 \cdot 2\end{array}$ \\
\hline $\begin{array}{l}\text { Hb- (Fam. S) } \\
\text { Hb-Russ }\end{array}$ & $\begin{array}{l}a \\
a\end{array}$ & $\begin{array}{l}19.4 \\
11.7\end{array}$ & $\begin{array}{l}1 \cdot 6 \dagger \\
2 \cdot 1 \dagger\end{array}$ & $\begin{array}{l}1.280 \\
1.265\end{array}$ & $\begin{array}{r}0 \\
-0.015\end{array}$ & $\begin{array}{l}3.2 \\
3 \cdot 0\end{array}$ \\
\hline
\end{tabular}

* The value given for normal hæmolysates is the moan of 13 determination with a standard deviation of the mean of 0.010 . All other values are mean values of duplicate determinations with the exception of those given for Hb-Dpunt tb hæmolysates, which are the mean of four separate analyses.

+ The percentages of the corresponding abnormal (in $\alpha$-chain) Hb-A (omponents were 0.8 for $\mathrm{Hb}-\mathrm{D} a, 0-7$ for $\mathrm{Hb}-\mathrm{I}$ and 0.4 for Hb-Russ.

The results of the oxygen equilibrium investigations are also summarized in Table $\mathbf{I}$; the oxygen affinities are presented as the logarithms of the oxygen pressures required to half-saturate the different hæmolysates, while the slopes of the oxygen dissociation curves are described by the values found for the constant $n$ in Hill's equation ${ }^{15}$. All different hæmolysates, except one, have oxygen affinities identical to that of a hæmolysate of normal adult red blood cells. The data obtained in several experiments with hæmolysates of red blood cells of an HbPunjab trait carrier indicate that the presence of this abnormal hæmoglobin increases the oxygen affinity, the differenc. being slightly greater than twice the standard deviation of the mean. A similar small difference was observed when blood samples of Hb-Dpunjab trait carriers wer" analysed. The values for the $\log \mathrm{P}_{50}$ values at $37^{\circ}$ and $p H \quad 7.4$ were 1.300 for the $D$ trait carrier and 1.32 .7 for the normal control. These results, which are in accordance with the observations made with isolated Hb-D Punjab (ref. 1), suggest that the structural abnormal. ity in this hæmoglobin type, namely, the replacement of a glutamic acid residue by glutamine in position 121 of the $\alpha$-chain, does interfere with the affinity for molecular oxygen. It might be argued that the results from the experiments with the other six hæmoglobin solutions do not definitely prove that the structural changes in these abnormal hæmoglobin types do not interfere with their oxygen equilibria, since mixtures with varying percentages of normal hæmoglobin types were investigated. It seems, however, that such differences, if present, are too small to change the physiological characteristics of hæmolysates prepared from these red blood cells.

We thank Mr. R. Lee for his help in locating the carriers of the abnormal hæmoglobin types investigated. This work was supported by U.S. Public Health Services grant $H-6982$.

T. H. J. HUISMAN

T. M. SCHILIHORN VAN VEeN

Department of Biochemistry,

Medical College of Georgia, Augusta.

Huism tn, T. H. J., Still, J., and Nechtman, C. M., Biochim. Fiophys, Arda. 74, 69 (1963)

" Chernoff, A. I., New England J. Med., 253, 322 (1955).

"Rigrss, A. (personal communication, 1962).

${ }^{4}$ Huisman, T. H. J., Dozy, A. M., Nechtman, C. M.. and Thompson, R. H., Nature, 195, 1109 (1962).

Baglioni, C., Proc. U.S. Nat. Acad. Sei., 48, 1800 (1962).

'Benesch, R. E., Ranney, H. M., Benesch, R., and Smith, (x. Y.. J. Him. Chem, 236, 2926 (1961).

Horton, B., Thompson, R. B., Dozy, A. M., Nechtman, C. M. Nichols. F. and Hutisman, T. H. J., Blood, 20, 302 (1962).

${ }^{4}$ Huisman, 'T. H. J., and Meyering, C. A., Clin. Chim. Acta, 5, 10? (1960).

"Huisman, T. H. J., and Dozy, A. M., J. Chiomatoy., ry, 180 (1962)

"Sydenstricker, V. P., Horton, B., Paỵne, R. A., and Huisman. 'T. H. ו.. Clin. Chim. Acta, 6, 677 (1961).

"Huisman, T. H. J., Adv. Clin. Chem. (in the press).

Bowman, R., and Ingram, V. M., Biochim. Birphys. A Ato, 53. 569 (1961).

13 Nurayama, M., Nature, 196, 276 (1962).

"Huisman, T. H. .., and sydenstricker. V. P. Nature. 193. tri) (196:).

1. Hill. A. V...J. Physiol., 40, 4 (1910).

\section{Ellipsometer Recordings of Changes in Optical Thickness of Adsorbed Films associated with Surface Activation of Blood Clotting}

Recent publications ${ }^{1-4}$ indicate that when blood comes into contact with glass. Factor XII is adsorbed and in turn adsorbs Factor XI. Much of the resulting 'activation product' can be recovered from the adsorbing surface ${ }^{1.3}$, but other indirect evidence shows that measurable amounts are released $d^{4-7}$.

To observe adsorption directly at a wettable solid interface before and during surface activation. a recording ellipsometer was used in our work. Details of technique were described elsewhere ${ }^{8,9}$. As reflecting adsorbents, the following were used: tantalum-sputtered glass object slides, anodized to form an optically sensitive thickness of oxide, and with an approximately $25 \AA$ thicker oxide step at one end of the slide for calibration of the recorder span at the beginning of each experiment; and slices of silicon crystal which could be rendered wettable by exposure to hot nitric acid. Normal intact (non-activated) 